УДК 007:[004.3+004.7]:001.891.3 JEL Classification: C63, D85

O. L. Yershova,

PhD in Economics, Associate Professor,

Head of the Department of Economics and Mathematical Disciplines

and Information Technology,

National Academy of Statistics, Accounting and Audit,

E-mail: bogi2003@ukr.net

ORCID: https://orcid.org/0000-0002-3801-9730;

L. I. Bazhan,

$P h D$ in Economics, Senior Researcher,

Head of the Department of Economic and Social Systems,

International Research and Training Center for Information Technologies and Systems

under NAS and MES of Ukraine,

E-mail: bazmil@ukr.net

ORCID: 0000-0002-6211-202X

\title{
The Conceptual Framework for Operation of Cyber-Physical Systems
}

Scientific studies focused on search for ways of building and operating cyber-physical systems are important because integration of physical processes, devices and data by use of cyber-physical systems creates new capacities for control of the physical world, including devices, manufacturing facilities and infrastructures, and opens up new real perspectives for national economies. The object of the study is cyber-physical systems for solving the problems of intellectual control of physical objects. The study is conducted as a contribution in building up a conceptual model of the cyber-physical system's interactions with the external environment. A generalized scheme of such interaction model is proposed with accounting for feedback, which positive role is that it enables for identification of disturbing impacts on the state of the physical environment, resulting in uncertainties of the latter's operation. The main functions of feedback in a cyber-physical system is to help produce controlling impacts on a controlled object by use of intellectual control, due to compensating disturbances and maintaining the state of stable equilibrium of the system. Several existing approaches to building conceptual models of cyber-physical systems which interaction with the environment are twodimensional: cybernetic and physical. The article's objective is to build a model for taking a controlling decision in cybernetic systems. Its result is an elaborated generalized scheme for taking a controlling decision in such systems. This generalized scheme is based on the information model, which components are interaction of a cyber-physical system with objects of the physical environment, with other systems and a system of artificial intellect, and with the following processes: measuring and computing processes, controlling processes, and communication processes. The described information model helps eliminate the consequences of unpredictable behavior of a cyber-physical system. The presented results are a contribution in the studies on effective control of physical objects, actively elaborated today. Use of the proposed components of the conceptual model will enable to increase the effectiveness of system monitoring of the operation of a physical object given better justification of taken decisions.

Key words: cyber-physical system, cybernetic space, physical space, interaction loop, conceptual model of cyber-physical systems.

Introduction. A cyber-physical system (CPS) is integration of computations, networks and physical processes. Real time sensors, real time devices, computers and networks control and monitor physical processes with feedback cycles, with physical processes having impact on computations and vice versa.

Formulation and adoption of unified flexible decisions in the field of CPS development and operation are complicated tasks. They can be solved by elaborating the following issues: to outline approaches to constructing conceptual models of CPS; to build a generalized scheme of CPS interactions with the

(C) O. L. Yershova, L. I. Bazhan, 2019 environment; to define a set of main CPS components; to elaborate on the problem of coordinating CPS interactions with physical processes and propose a conceptual model for integration of CPS components.

Importance of the study. Connection of Internet with material things opens up new opportunities for control of the physical world, including devices, production equipment and infrastructure that determine the contemporary economic landscape. Integration of physical processes, devices and data by use of networks opens up new real prospects for national economies. In the forthcoming 10 years Internet of things may radically change the manufacturing industry, energy supply, agriculture, transport and other industries of the real sector 
that account for nearly two thirds of the global GDP. Being associated with digitalization processes, these transformations will have far-reaching effects for redistribution of resources and markets of the contemporary world. Bearing this in mind, the researchers' effort aimed to find universal laws and principles for building and operating CPS has critical importance.

A review of recent literary sources on this problem shows three tendencies in the attempts to unify approaches to CPS building [1]. The first tendency is based on the conception of multilevel systems, which implies construction of various options of hierarchical CPS structures where each next higher level includes operation details of the lower levels. Five CPS levels are proposed in [2]: 1) smart connection level; 2) data-to-information conversion level; 3) cyber level; 4) cognition level; 5) configurations level. In another approach within this tendency, three types of tiers on the overall CPS structure are determined [3]: 1) environmental tiers; 2) service tiers; 3 ) control tiers.

The second tendency is focused on various types of cybernetics devices, with proposing various options of their classification, unification and stratification by CPS level [3-4]. For example, in module-based architecture for CPS, six unified CPS modules are set: 1) sensing module; 2) data management module; 3 ) next-generation Internet; 4) service aware modules; 5) application module; 6) sensors and actuators [3].

The third tendency uses the notion of "service" as the classification criterion, on which the multitier CPS structure is built. Thus, in the servicebased architecture for CPS [3], two main types of services are distinguished: device bundle and agent service, located at the second tier of the three-tier CPS structure: 1) physical tier; 2) service tier; 3) application tier. In another case of the ServiceOriented Architecture of CPS, the CPS structure is divided into four layers: 1) service implementation layer; 2) service abstraction layer; 3) business process layer; 4) application layer [3].

The considerable productive effort in formulating the unified principles for building and operating CPS is shown in works on mathematical modeling of CPS [5-8].

Results. The end of the past century witnessed the extended applications of methods from information theory and physical objects control, which essentially change the behavior of systems being in chaotic regimes. The concept of the system's interactions with the environment is based on the communication rather than the action. This approach enables to consider not only physical and energy interactions of a system and the environment, but their information interactions as well. Unable to control all the system's operations, the environment still can have impact on some of them, triggering constant deviations, which, in turn, cause structural change in a system, breaking its equilibrium [9].

Cybernetics systems refer to the system in which one part of the components is objects of the real world, while the other part is virtual, information objects. CPS combines the capacity to computations, communications and information storage with monitoring and control of the real world objects, which is effective for the system operation in the real time regime.

CPS is a distributed system with intellectual control responsible for coordination of computing and physical components [10]. The computing CPS components interact with sensors enabling for monitoring of cyber-physical indicators, and with executive components altering the cyberphysical environment. The information received from intellectual sensors distributed in the physical environment by use of software enables for analysis of the data coming from the sensors in the real time, information about events, and to embed them in intellectual decisions.

The system's control can be considered as making transitions between its states. The system's state is characterized by its parameters that take some stationary values. The course of events in any system, being under the constant impact of external factors, tends to be random. Due to the system's complexity and volatility in time, its behavior is in a way uncertain, probabilistic. As a result of multiple uncertainties, CPS will always be a system with incomplete information, and its control will always be performed in the conditions of uncertainty.

A system, if got out of an equilibrium or stationary state, must be able to return to stationary characteristics within the stability boundaries, which requires a control action.

A necessary condition for the effective CPS operation in the conditions of uncertainty is the existence of feedback signaling a result achieved due to control actions. The law of feedback, a fundamental law of cybernetics, states that when there is no feedback between causally linked and interacting components of a system, its effective control cannot be set. The functions of feedback are confined to informing, to reflect the change in the system's state resulting from the control action. The processes of control, adaptation, self-regulation and development are impossible without use of feedbacks [11]. By use of feedback, information about the work performed by an object of control is transmitted from the system's (object's of control) point of discharge to the controlling body. Here this information is compared with the information setting the contents and scopes of work. When a deviation between actual and planned states occurs, actions to prevent it will be taken. 
The main functions of feedback are as follows:

1. To counteract to whatever is done by a system, when it gets out of the set boundaries;

2. To compensate disturbances and maintain the state of the stable equilibrium of a system;

3. To synthesize internal and external disturbances seeking to get a system out of the state of stable equilibrium, to confine these disturbances to deviations of one or several controlling values;
4. To produce controlling impacts on the controlled object by use of intellectual control.

5. The controlling impact is adjusted on the basis of this information. In a simplified form it is shown in Figure 1. The input value $\mathrm{x}_{i}$ acts on the controlled process and, according to the transmission function, determines the ratio between input and output signals $\mathrm{u}_{n}$, and transforms into the output value $\mathrm{y}_{m}$.

Input

Output

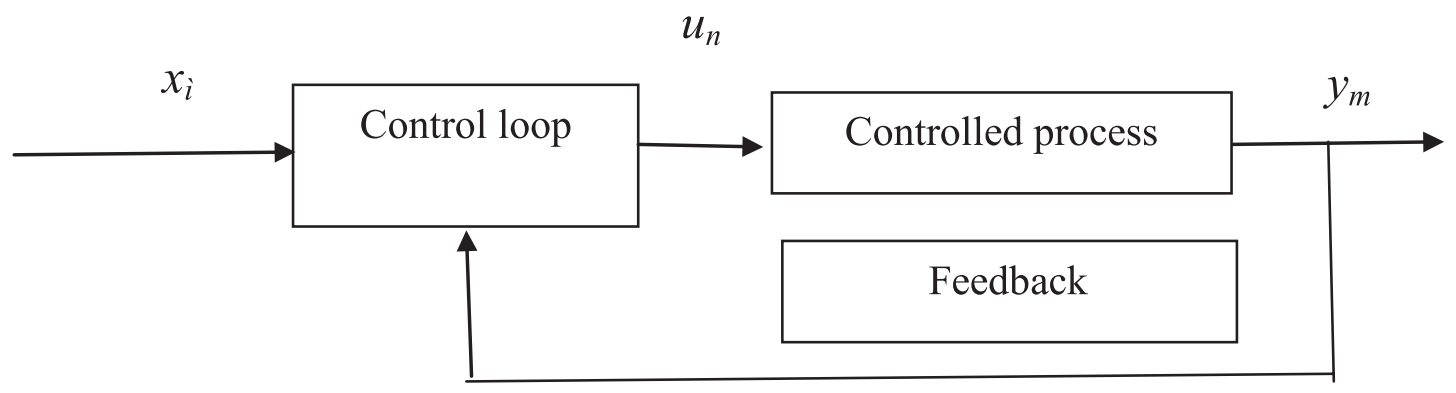

Fig. 1. The scheme of system's control with feedback

Two types of feedback are distinguished: negative, which decreases the impact of an input value on an output value, setting some stable dynamic equilibrium; and positive, which increases this impact, causing thereby unstable equilibrium. It means that a negative feedback helps renew the normal work of a system, broken by external and internal factors, i. e. it determines the system's capacity for self-regulation and self-organization (adaptation). The positive role of a feedback is that by informing data on the real state of a physical object to the controlling body it enables to perform regulation in the conditions of incomplete information about disturbing impacts.

In cybernetics, a feedback is considered as an information process. The impact of an input signal on a physical object, its transformation into an output signal and the reverse impact of the discharge through the feedback channel on an input value are the processes of transmission and processing of information [4].

The distinctive features of CPS are as follows:

- high degree of the system's computerization, the continuing telecommunication contact (information exchange) with analogous systems, interactions with the global Internet;

- the existence of a center (a subsystem) for computerized control over the system's operation and assurance of its stable workability given various disturbing impacts;

- the existence of the single information environment, the cyber environment, encompassing a set of software and hardware for information processing and transmission, information exchange within a system and between a system and the external environ- ment, the system of computerized control of physical components by use of logically programmed controllers, support of the set work scenario with the possibility of adaptive control;

- high intellectual capacity of control by building work scenarios through forecasting and adaptive control, which assures the systems' stability.

The logical framework of CPS consists of: 1) a set of causally linked physical components, realizing the technological process; 2) a set of causally linked information components exercising control of the process in various degrees of computerization; 3) a communication environment enabling for information exchange within a system and between s system and the external environment, and for transmission of controlling commands through the control loop by the executive mechanism. This scheme is shown in Figure 2.

CPS interaction with the external environment can be described by the information model. The information model is a model of an object presented in form of information describing the essential parameters and variables of an object, their feedbacks, the object's inputs and outputs, which enables for modeling potential states of an object by sending information about changes in the input values to the model.

The information model of CPS can be built in three phases [1]:

1. The scheme of CPS interactions with the external environment.

2. The scheme of operation of CPS components.

3. The loop of CPS interactions with physical objects. 


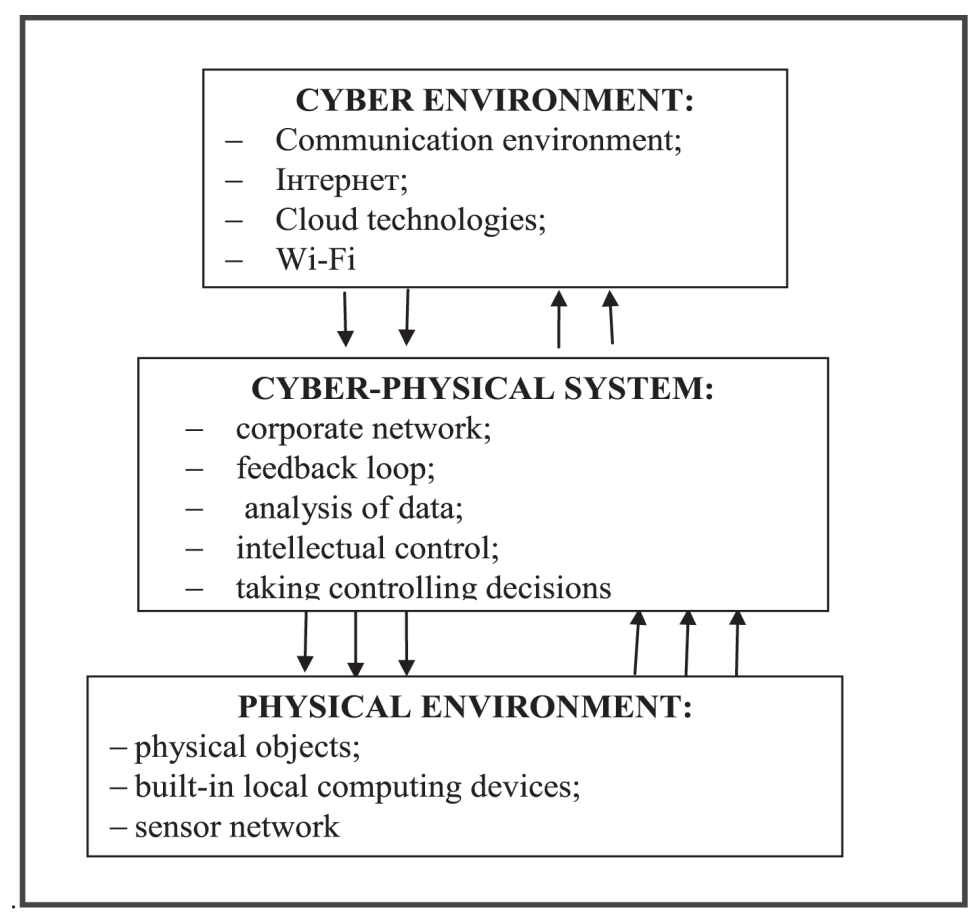

Fig. 2. The conceptual scheme of the cyber-physical system

Information $x_{i}$ comes to the CPS input. The scheme of CPS interactions with the external environment is considered from the moment of incoming data $x_{i}$ to the system's input, where $x_{i} \in X_{i}, i$ is one of the options of system's operation, which, under the control by $u_{i}$, where $u_{i} \in U_{i}$, form the current state of CPS $s_{j}$, where $s_{j} \in S_{j}$. At the system's output we will receive information $y_{m}$ (where $y_{m} \in Y_{m}$ ), controlling actions $v_{n}\left(\right.$ where $\left.v_{n} \in V_{n}\right)$. Then the CPS interactions with the external environment can be presented as cortege $<X_{i}, U_{i}, Y_{m}, S_{j}, V_{j}, T_{i}, T_{j}>$, where operator $T_{i}:\left(X_{i}, U_{j}\right) \cdot S_{j} \rightarrow V_{j}$ transforms input data, controlling actions and the current state of a system into the output data, whereas operator $T_{j:}\left(X_{i}, U_{j}\right) \cdot S_{j} \rightarrow Y_{m}$ transforms input data, controlling actions and the current state of the system into the controlling actions.

A core objective of CPS operation is selecting its structure and parameters $x_{i}$ in a way to maximize its target function $F(S)=o p t f\left(x_{i}\right)$, where all the potential options of CPS operation $S_{j} \in S$ are considered.

The CPS behavior is characterized by three processes:

- CPS interactions with objects of the physical environment;

- CPS interactions with people, other systems, the system of artificial intellect.

- interactions of CPS components with measurement and computation processes, processes of control, communication processes.

Each of the above interactions brings disturbing actions in the process of CPS operation, which cause instability. A component constituting a part of the system enters in relations with other subsystems or components. Also, the diversity of components and their spatial disconnection, high dynamics of change in the physical environment cause the need for constructing a multi-criteria assessment of the effectiveness of CPS operation, which may be incompatible in terms of their coherence.

The main components of CPS are as follows:

- executive system: hardware and software control;

- sensor system (analyzers): a set of means that absorb, transmit and analyze information from the system's external and internal environment;

- built-in computing devices (sensors): devices collecting data from the physical environment and transmitting them to the digital environment;

- high performing computing devices;

- devices for storage and processing data inside the physical environment: IT infrastructure;

- devices for taking controlling decisions: enable for taking decisions on control over the physical environment;

- devices for human's interactions with CPS: human-machine interface;

- communication devices: technologies for data transmission, infrastructures for data exchange between the digital and physical environment;

- devices for analysis and processing of data: devices enabling for analysis and processing of data;

- technologies of intellectual control. They are important because decisions on control of interactions between complex processes are taken in the conditions of uncertain impact from external factors and unfavorable change in internal parameters of the processes, uncertainty of the estimated consequences of taken decisions, sometimes contradictory objectives and criteria of process control. 
Consider $p$-th physical process of CPS, in which $S(p)$ is the sensor system, and $V(p)$ is the executive system, $R e$ - built-in computing devices (sensors), and $\operatorname{Re}(S)$ are devices for storage of data inside the physical environment, $\operatorname{Re}(V)$ are devices for the physical environment control; $R_{g}$ are high performing computing devices; $R_{g}(S)$ are devices for data processing inside the physical environment; $R_{g}(M)$ are devices for analysis of data of the physical environment; $R_{g}(V)$ are devices for taking decisions on control over the physical environment. Using the proposed symbols, the following component clusters can be presented:

$$
\text { [( } S(p), \operatorname{Re}(S)),(V(p), \operatorname{Re}(V))]
$$

- data storage inside the physical environment and the latter's control;

$$
\text { [( } \left.\left.R_{g}(S), R_{g}(M), R_{g}(V)\right)\right]
$$

- data processing inside the physical environment and taking decisions on the latter's control.

The conceptual model for organization of operation of CPS components can be presented as follows [5]:

$$
\begin{aligned}
M_{F}=\{ & {[(S(p), \operatorname{Re}(S)),(V(p), \operatorname{Re}(V))], } \\
& {\left.\left[\left(R_{g}(S), R_{g}(M), R_{g}(V)\right)\right]\right\} \cdot P, }
\end{aligned}
$$

where $P=\{p\}$ is unlimited numbers of physical processes caused by feedback effects.

Conclusions. One of the CPS applications is smart industry. CPS can be applied in manufacturing, health care, renewable energy, intellectual buildings, transport, agriculture, computing environments. The industrial revolution 4.0 is rapidly transforming the world. Modern technologies (ICT), mathematical methods, advances technical and software facilities will have impact on all the human spheres. Developed economies will have a chance to bring the manufacturing back home from Eastern "factory countries". The close-to-consumer massscale manufacturing and wide-scale applications of smart things and mechanisms integrated by Internet create a new reality that opens up new opportunities, but also brings new challenges and problems. All of them have to be rethought at the political level and translated into national strategic initiatives on $\mathrm{R} \& \mathrm{D}$ intensive and high tech development of the national economy and its leading sector, smart industry. Of special importance in each case is finding solution to the problem of investment in building and implementation of CPS.
In the global economy, industries with a wide product line, such as automobile or food, will gain advantage from the flexibility of CPS and productivity growth. Industries requiring high quality, such as electronics and pharmaceutics, will gain advantage from use of big data and analytics, the continuing improvement of quality and functionality of products. In overall, more flexible, rapid and effective ways of producing high quality goods with lower prices are supposed to push up economic growth and increase the numbers of skilled jobs, changing the competitiveness of companies and regions.

Studies of the conceptual framework for building and operating CPS help foster the awareness of problems related with the existence and development of real smart economy objects and enable to assess the complexity of each system. This article does not address issues related with impact of the human factor on CPS operation, because humans (executors, consumers, managers) exist apart from components or environments. Because their involvement gives rise to many circumstances and situations, consideration for the human factor in future studies of CPS is justified and necessary.

Prospects of further development of CPS are associated with the wide-scale implementation of digital monitoring and active optimal control (without involvement of humans) of all the physical, biological, social, economic, technological, financial, scientific and education processes across the world, in countries, cities, organizations, companies, social groups and households.

Further studies of the authors will be devoted to building of conceptual CPS models for specific physical objects in the conditions of real operation. The parallel dynamic adaptation of the parameters of the set of procedures for monitoring, assessment and forecasting of technological processes, considering the impact of evolutionary and exploitation factors, will help enhance the effectiveness of management decisions.

The scientific results presented in this article are produced as part of the scientific work "Investigation of some aspects of operation of socio-economic systems in the digital economy", registration number 0118 U006677.

\section{References}

1. Holembo, V., Bochkarov, O. (2017). Pidkhody do pobudovy kontseptualnykh modelei kiberfizychnykh system [Approaches to the construction of conceptual models of cyber-physical systems]. Visnyk Natsionalnoho universytetu "Lvivska politekhnika". Kompiuterni nauky ta informatsiini tekhnolohii - Bulletin of National University "Lvivska Politekhnika". Computer sciences and information technologies, 864, 168-178. Retrieved from http://nbuv.gov.ua/UJRN/VNULPKNIT_2017_864_24 [in Ukrainian].

2. Lee, J., Bagheri, B., Hung-An, K. (2015). A Cyber-Physical Systems architecture for Industry 4.0-based manufacturing systems. Manufacturing Letters, 3, 18-23. 
3. Bhadoria, R. S., Yadav, R., \& Tomar, G. S. (2015). Architectural Analysis of Cyber-Physical Systems. Cyber Physical Systems - A Computational Perspective. G. M. Siddesh, G. Ch. Deka, K. G. Srinivasa \& L. M. Patnaik (Eds.). New York: Chapman and Hall/CRC. DOI: https://doi.org/10.1201/b19206

4. Fouquet, F., Barais, O., Plouzeau, N., Jézéquel, J.-M., Morin B., \& Fleurey, F. (2012). A Dynamic Component Model for Cyber Physical Systems. hal.inria.fr. Retrieved from https://hal.inria.fr/hal-00713769/document

5. Claytex (2017). Dymola for physical modelling and simulation using Modelica. wrere.claytex.com. Retrieved from http: //www.claytex.com/products/dymola/ (Last accessed 28.09.2017).

6. Madykh, A. A., \& Okhten, A. A. (2018). Modelirovanie transformatsii vliianiia proizvodstvennykh faktorov na ekonomiku v protsesse stanovleniia smart-promyshlennosti [Modeling of transformation of the production factors' impact on the economy in the process of smart economy formation]. Ekonomika promyshlennosti - Industrial Economics, 4 (84), 26-41 [in Russian].

7. Karnopp, D., Margolis, D., \& Rosenberg, R. (1997). System dynamics: modeling and simulation of mechatronic systems. New York: Wiley.

8. Mosterman, P., \& Biswas, G. (1998). A theory of discontinuities in physical system models. Journal of the Franklin Institute, 335 (3), 401-439.

9. Fradkov, A. L. (2005). O primenenii kiberneticheskikh metodov v fizike [Applications of cybernetic methods in physics]. Uspekhi fizicheskikh nauk - Physics - Uspekhi, Vol. 105, 2, 113-138 [in Russian].

10. Gritsenko, V. I., Bazhan, L. I., \& Yershova, O. L. (2019). Cyber Physical System - Distributed System of Intelligent Control. Control Systems and Computers, 2, 3-10.

11. Novikov, D. A. (2016). Kibernetika: Navigator. Istoriia kibernetiki, sovremennoe sostoianie, perspektivy razvitiya [Cybernetics: Natigator. History of cybernetics, current state, development prospects]. Moscow: LENAND [in Russian].

12. Fradkov, A. L. (2003). Kiberneticheskaya fizika: printsipy i primery [Cybernetic physics: principles and examples]. S.-Petersburg: Nauka [in Russian].

\section{О. Л. Єршова,}

кандидат економічних наук, доцент,

завідувач кафедри економіко-математичних

дисциплін та інформаційних технологій,

Національна академія статистики, обліку та аудиту,

E-mail: bogi2003@ukr.net

ORCID: https://orcid.org/0000-0002-3801-9730;

\section{Л. I. Бажан,}

кандидат економічних наук, старший науковий співробітник,

завідувач відділу економіко-соціальних систем,

Міжнародний науково-навчальний центр

інформаційних технологій та систем НАН України та МОН України,

E-mail:bazmil@ukr.net

ORCID: 0000-0002-6211-202X

\section{Концептуальні основи функціонування кіберфізичних систем}

Актуальність наукових розвідок, спрямованих на пошук можливостей побудови і функціонування кіберфізичних систем, обумовлена тим, що поєднання фізичних процесів, пристроїв та даних за допомогою мереж формує нові можливості управління фізичним світом, включаючи пристрої, виробниче устаткування та інфраструктуру, та відкриває нові реальні перспективи для національних економік. Об’єктом дослідження є кіберфізичні системи для розв'язання задач інтелектуального управління фізичними об’єктами. Дослідження проведені в рамках формування концептуальної моделі взаємодії кіберфізичної системи із зовнішнім середовищем. Запропонована узагальнена схема такої моделі взаємодії з урахуванням зворотного зв'язку, позитивна роль якого полягає в уможливленні ідентифікації збурюючих впливів на стан фізичного середовища, що призводять до невизначності функціонування останнього. Основні функції зворотного зв'язку в кіберфізичній системі полягають у сприянні виробленню управлінських впливів на керований об’єкт за допомогою інтелектуального управління завдяки компенсації збурень і підтриманню стану стійкої рівноваги системи. Розглянуті деякі існуючі підходи до побудови концептуальних моделей кіберфізичних систем, взаємодія яких з оточенням відбувається одночасно у двох просторах: кібернетичному та фізичному. Метою статті є формування моделі прийняття управлінського рішення в кібернетичних системах. Результатом є розробка загальної схеми прийняття управлінського рішення в таких системах. Зазначена загальна схема базується на інформаційній моделі, компонентами якої є взаємодія кіберфізичної системи з об'єктами фізичного середовища, з іншими сис- 
темами та системою штучного інтелекту, а також з такими процесами: вимірювально-обчислювальними, управління та комунікаційними. Описана інформаційна модель сприяє подоланню наслідків непередбачуваної поведінки кіберфізичної системи. Представлені результати є внеском у дослідження за активно розроблюваним нині напрямом ефективного управління фізичними об'єктами. Застосування запропонованих елементів концептуальної моделі дозволить збільшити ефективність системного моніторингу функціонування фізичного об'єкта за умови підвищення ступеня обгрунтованості прийнятих рішень.

Ключові слова: кіберфізична система, кібернетичний простір, фізичний простір, контур взаємодіі, конщептуальна модель кіберфізичних систем.

Bibliographic description for quoting:

Yershova, O. L., \& Bazhan, L. I. (2019). The Conceptual Framework for Operation of Cyber-Physical Systems. Statystyka Ukrainy - Statistics of Ukraine, 3, 63-67. Doi: 10.31767/su. 3(86)2019.03.07.

Бібліографічний опис для цитування:

Єршова О. Л., Бажан Л. І. Концептуальні основи функціонування кіберфізичних систем (публікується англійською мовою) // Статистика України. 2019. № 3. С. 63-67. Doi: 10.31767/su. 3(86)2019.03.07. 